\title{
Application of lactic acid bacteria producing antifungal substance and carboxylesterase on whole crop rice silage with different dry matter
}

\author{
Seong Shin Lee ${ }^{1, a}$, Dimas Hand Vidya Paradhipta ${ }^{1,2, a}$, Hyuk Jun Lee ${ }^{1}$, Young Ho Joo ${ }^{1}$, \\ Hyeon Tak Noh ${ }^{1}$, Jeong Seok Choi ${ }^{1}$, Keum Bae $\mathrm{Ji}^{3}$, and Sam Churl Kim ${ }^{1}$ «*
}

\author{
* Corresponding Author: Sam Churl Kim \\ Tel: +82-55-772-1947, Fax: +82-55-772-1949, \\ E-mail:kimsc@gnu.ac.kr \\ 1 Division of Applied Life Science (BK21Four, \\ Insti. of Agri. \& Life Sci.), Gyeongsang \\ National University, Jinju 52828, Korea \\ ${ }^{2}$ Faculty of Animal Science, Universitas \\ Gadjah Mada, Yogyakarta 55281, Indonesia \\ ${ }^{3}$ Institute of Technology, Livemac Co. Ltd. \\ Gimje 54329, Korea \\ a These authors contributed equally to this \\ study. \\ ORCID \\ Seong Shin Lee \\ https://orcid.org/0000-0002-4872-3705 \\ Dimas Hand Vidya Paradhipta \\ https://orcid.org/0000-0001-7233-469X \\ Hyuk Jun Lee \\ https://orcid.org/0000-0003-4766-6742 \\ Young Ho JoO \\ https://orcid.org/0000-0002-3041-623X \\ Hyeon Tak Noh \\ https://orcid.org/0000-0002-2489-071X \\ Jeong Seok Cho \\ https://orcid.org/0000-0002-6586-186X \\ Keum Bae Ji \\ https://orcid.org/0000-0002-6076-8826 \\ Sam Churl Kim \\ https://orcid.org/0000-0003-3105-0118
}

Submitted Aug 3, 2020; Revised Sept 9, 2020; Accepted Oct 5, 2020
Objective: This study was conducted to investigate effects of antifungal substance and carboxylesterase-producing inoculant on fermentation indices and rumen degradation kinetics of whole crop rice (WCR) silage ensiled at different dry matter (DM) contents.

Methods: Dual-purpose inoculants, Lactobacillus brevis 5M2 and Lactobacillus buchneri $6 \mathrm{M} 1$, confirmed both activities of antifungal and carboxylesterase in the previous study. The WCR at mature stage was chopped, and then wilted to obtain three different DM contents consisting of $35.4 \%, 43.6 \%$, and $51.5 \%$. All WCR forages were applied distilled water $(\mathrm{CON})$ or mixed inoculants with $1: 1$ ratio at $1 \times 10^{5}$ colony forming unit/g (INO), and ensiled into $20 \mathrm{~L}$ mini silo $(5 \mathrm{~kg})$ in quadruplicates for $108 \mathrm{~d}$.

Results: The INO silages had lower lactate $(\mathrm{p}<0.001)$ and butyrate $(\mathrm{p}=0.022)$ with higher acetate $(\mathrm{p}<0.001)$ and propionate $(\mathrm{p}<0.001)$ than those of CON silages. Ammonia-N $(p<0.001)$, lactate (tendency; $p=0.068)$, acetate $(p=0.030)$, and butyrate $(p<0.001)$ concentrations of INO silages decreased linearly with increasing DM content of WCR forage. The INO silages presented higher lactic acid bacteria $(\mathrm{p}<0.001)$ with lower molds $(\mathrm{p}<$ $0.001)$ than those of CON silages. Yeasts $(p=0.042)$ and molds $(p=0.046)$ of WCR silages decreased linearly with increasing DM content of WCR forage. In the rumen, INO silages had higher the total degradable fraction $(\mathrm{p}<0.001)$, total volatile fatty acid (tendency; $p=0.097)$, and acetate $(p=0.007)$, but lower the fractional degradation rate $(\mathrm{p}=0.011)$ and propionate $(\mathrm{p}<0.001)$ than those of CON silage. The total degradable fraction $(p<0.001)$, total volatile fatty acid $(p=0.001)$, iso-butyrate $(p=0.036)$, and valerate $(p=0.008)$ decreased linearly with increasing DM content of WCR forage, while the lag phase $(\mathrm{p}<0.001)$ was increased linearly.

Conclusion: This study concluded that application of dual-purpose inoculants on WCR silage confirmed antifungal and carboxylesterase activities by inhibiting mold and improving rumen digestibility, while increase of wilting times decreased organic acids production and rumen digestibility.

Keywords: Haylage; Lactic Acid Bacteria; Rumen Fermentation; Silage; Whole Crop Rice

\section{INTRODUCTION}

An inhibition of undesirable microbes and an increase of nutrient digestibility are the main foci in silage studies. The growths of yeast and mold decrease the nutrient quality of silage and produce harmful substances for ruminants [1]. In addition, digestibility of silage decreases with increasing lignocellulose content. Rumen microbes are capable of producing cellulase or hemicellulase, but they release limited enzymes to breakdown lignocellulose [2]. The previous investigations revealed that several strains of lactic acid bacteria (LAB) 
could produce antifungal substances to inhibit growth undesirable microbes [3-5] and carboxylesterase to break down lignincellulose $[1,4,5]$. However, the ability of LAB to produce antifungal or carboxylesterase activities during ensiling were depended on strains and substrate sources $[1,6]$.

In South-East Asia, rice straw is abundant and has become one of the biggest forage sources for feeding ruminants, such as cattle, goat, sheep, and even buffaloes [7]. After harvesting, the rice straw commonly is preserved by making silage or hay. However, it has poor content of soluble carbohydrate after separating from its grains, which results in a low fermentation quality when it is preserved as silage [8]. The LAB cannot grow optimally with low content of soluble carbohydrate leading an inability to drop the $\mathrm{pH}$ rapidly during ensiling [9]. In addition, the maillard reaction and an increase of yeast and mold can occur as the consequence of low fermentation quality in the silage [9]. Ensiling rice straw together with its grains provides more water soluble carbohydrate that can increase organic acid concentration produced by $\mathrm{LAB}$, and thus improve fermentation quality. Even though the fermentation quality can be increased, whole crop rice (WCR) at maturity stage contains a lot of lignocellulose that decreases digestibility. Thus, appropriate LAB producing antifungal and esterase activities are required to improve fermentation and digestibility of WCR silage.

In our previous study, new dual-purpose inoculants consisting of Lactobacillus brevis (L. brevis) 5M2 KACC 92268P and Lactobacillus buchneri (L. buchneri) 6M1 KACC 92269P were obtained from corn silages ensiled at beef cattle farms through a bacterial strain isolation procedure based on antifungal activity against Fusarium graminearum and carboxylesterase activity [4]. In the application, isolation of baled-corn silage with mixed those LAB confirmed an antifungal effect by decreasing yeast contamination and a carboxylesterase effect by increasing nutrient digestibility in the rumen [4]. However, the effects of the isolated LAB in high lignified forage such as WCR were not tested. In hypothesis, application of new dual-purpose inoculants on WCR silage can decrease the contamination of undesirable microbes and increase nutrient digestibility in the rumen, but the effectiveness of antifungal and esterase activities may also be affected by dry matter (DM) content at ensiling. To investigate the DM effect, WCR forage was wilted in different times that represented the moisture content for making silage, haylage, and the intermediate condition between silage and haylage. Therefore, the purpose of the present study was to investigate the effect of new dual-purpose inoculant on fermentation indices and rumen degradation kinetics of WCR silage with different wilting times.

\section{MATERIALS AND METHODS}

\section{Inoculant preparation}

The L. brevis 5M2 KACC 92268P and L. buchneri 6M1 KACC 92269P (Korean Culture Center of Microorganism, Seoul, Korea) were grown respectively in lactobacilli MRS media at $30^{\circ} \mathrm{C}$ for $3 \mathrm{~d}$ in a $\mathrm{CO}_{2}$ incubator, and then adjusted with sterile ultra-pure distilled water to obtain $1 \times 10^{5}$ colony forming unit (cfu)/g of fresh forage as the recommended application rate $[4,5]$. Furthermore, these LABs were mixed at ratio 1:1 for silage inoculant.

\section{Silage production}

The WCR (Sindongjin hybrid) at mature stage was harvested from 2 ha paddy field at Animal Research Unit, Gyeongsang National Univeristy (Geumgok, Jinju, Gyeongnam, Korea) and chopped into 3 to $5 \mathrm{~cm}$ length using a conventional harvester (BHC-90; BUHEUNG Machinery Ltd., Jinju, Korea). The chopped WCR was wilted under the sun in different times to get specific DM contents following: i) low DM content, without wilting (LOW) containing $35.4 \% \mathrm{DM}$; ii) intermediate DM content, wilted to obtain 43.7\% DM (MED); and iii) high DM content, wilted to obtain 51.6\% DM (HIGH). The LOW and HIGH represented condition for making silage and haylage, respectively. The MED represented intermediate condition between silage and haylage. All forages were ensiled into $20 \mathrm{~L}$ mini silo (5 kg) for $108 \mathrm{~d}$ and were applied $1 \%$ distilled water in fresh forage (CON) or mixture of inoculants (INO). Each experimental treatment had four silos as replication, thus a total of 24 silos was used in the present study. The WCR before and after ensiling were sub-sampled at $500 \mathrm{~g}$, respectively, to analyses chemical composition and in vitro digestibility. Also, $20 \mathrm{~g}$ of ensiled WCR was sub-sampled and blended with $200 \mathrm{~mL}$ of sterile ultrapure water for $30 \mathrm{~s}$, and then filtered through two layers of cheesecloth to make silage extraction [3-5]. The fresh silage extraction was used to analyze $\mathrm{pH}$ and microbial counts. After then, silage extraction was stored at $-70^{\circ} \mathrm{C}$ until analyses of ammonia- $\mathrm{N}$, lactate, and volatile fatty acid (VFA).

\section{Chemical compositions}

Forage and silage samples were dried at $65^{\circ} \mathrm{C}$ for $48 \mathrm{~h}$ and ground to pass 1-mm screen using a cutting mill (Shinmyung Electric Co., Ltd, Gimpo, Korea) for the measurements of chemical compositions and in vitro digestibility at $48 \mathrm{~h}$, respectively. DM was determined by drying $10 \mathrm{~g}$ of sample in an forced-draft oven (OF-22GW; Jeio Tech, Seoul, Korea) at $105^{\circ} \mathrm{C}$ for $24 \mathrm{~h}$ and crude ash (CA) was determined with a muffle furnace at $550^{\circ} \mathrm{C}$ for $5 \mathrm{~h}$. Crude protein $(\mathrm{CP})$ and ether extract (EE) were determined by Kjeldahl (method 984.13 [10]) using N analyzer (B-324, 412, 435, and 719 S Titrino; BUCHI, Flawil, Switzerland) and Soxhlet (method 920.39; [10]), respectively. Following the procedure of AOAC [10], neutral detergent fiber (NDF; method 2002.04) and 
acid detergent fiber (ADF; method 973.18) were determined by using an Ankom ${ }^{200}$ Fiber Analyzer (Ankom Technology, Macedon, NY, USA). Hemicellulose (HEMI) was determined by calculating the differences between NDF and ADF.

\section{Fermentation indices}

Silage $\mathrm{pH}$ and ammonia-N were measured using $\mathrm{pH}$ meter (SevenEasy; Mettler Toledo, Greifensee, Switzerland) and the colorimetric method described by Chaney and Marbach [11], respectively. The silage extraction was centrifuged at $5,645 \times g$ for $15 \mathrm{~min}$ to separate supernatant from silage residue. Collected supernatant was used for lactate and VFA analyses. The concentrations of lactate and VFA were determined using HPLC (L-2200; Hitachi, Tokyo, Japan) fitted with a UV detector (L-2400; Hitachi, Tokyo, Japan) and a column (Metacarb 87H; Varian, Palo Alto, CA, USA) according to the method described by Muck and Dickerson [12].

\section{Microbial counts}

Silage extract (first dilution) was continued in several dilutions $\left(10^{-3}\right.$ to $\left.10^{-8}\right)$ to determine microbial counts such as $\mathrm{LAB}$, yeast, and mold. The silage extract was plated in triplicate selective agar medium. The lactobacilli MRS agar media (MRS; Difco, Detroit, MI, USA) was used for LAB count, and potato dextrose agar (PDA; Difco, USA) was used for yeast and mold counts. The MRS agar plates were placed in a $\mathrm{CO}_{2}$ incubator (Thermo Scientific, Waltham, MA, USA) at $28^{\circ} \mathrm{C}$ for $48 \mathrm{~h}$, while PDA plates were incubated at $28^{\circ} \mathrm{C}$ for $72 \mathrm{~h}$ in an aerobic incubator (Johnsam Corp., Boocheon, Korea) [3-5]. Visible colonies were counted from the plates and the number of cfu was expressed per gram of silage. The microbial data was transformed to $\log 10$.

\section{Rumen incubation}

The procedure of animal care was approved by animal ethical committee of Gyeongsang National University, Jinju, Korea (GNU-191011-E0050). The rumen fluid was collected from two non-pregnant cannulated Hanwoo heifers before morning feeding, their diets consisted of rice straw and commercial concentrate mix at 8:2 ratio. The collected rumen fluid was composited, and then filtered via two layers of cheesecloth. A rumen buffer was made by mixing rumen fluid with anaerobic culture medium at 1:2 ratio described by Adesogan et al [13]. Dried sample of WCR silage at 0.5 $\mathrm{g}$ was weigh into incubation bottle with $40 \mathrm{~mL}$ of rumen buffer. Then the incubation bottle was gassed with $\mathrm{CO}_{2}$ and closed tightly to reach anaerobic condition. Three replications for each treatment were used along with two blanks. Gas pressure was monitored in a computer every $30 \mathrm{~min}$ during $72 \mathrm{~h}$ using wireless automated system by $\mathrm{ANKOM}^{\mathrm{RF}}$ (ANKOM Technology, USA) to calculate degradation kinetics in the rumen [13]. These kinetics were generated from the gas pressure using nonlinear regression procedure of Statistical Analysis Sofware [14] to fit with the model of McDonald [15] following:

$$
\mathrm{Y}=\mathrm{A}+\mathrm{B}\left(1-\mathrm{e}^{-\mathrm{c}(\mathrm{t}-\mathrm{L})}\right) \text { for } \mathrm{t}>\mathrm{L}
$$

where $\mathrm{A}$ is the immediately degradable fraction; $\mathrm{B}$ is the potentially degradable fraction; $\mathrm{A}+\mathrm{B}$ is total degradable fraction; $\mathrm{C}$ is the fractional degradation rate; $\mathrm{L}$ is the lag phase; and $\mathrm{t}$ is time of incubation (h).

After incubation, bottles were opened and transferred to $50 \mathrm{~mL}$ conical tubes to separate remains sample and supernatant (rumen buffer) through centrifugation at 2,568 $\times g$ for 15 min (Supra 21k; Hanil Electric Corporation, Seoul, Korea, with rotor A50S-6C No.6). The supernatant was used to analyze rumen fermentation indices such as $\mathrm{pH}$, ammonia- $\mathrm{N}$, and VFA $[4,5]$. The procedure for analyses of $\mathrm{pH}$, ammonia$\mathrm{N}$, and VFA were same as described in previous section of materials and methods.

\section{Statistical analysis}

The experiment was conducted by a 2 (Inoculant; CON vs INO $) \times 3$ (DM content; LOW vs MED vs HIGH) factorial design with four replicates per treatment and all data were analyzed using PROC MIXED of statistical analysis system (SAS), version 9.3 package program [14] to test the effects of inoculant, $\mathrm{DM}$ content, and its interaction (inoculant $\times \mathrm{DM}$ content). The model was $Y_{i j k}=\mu+\alpha_{i}+\beta_{j}+(\alpha \beta)_{i j}+e_{i j k}$, where $Y_{i j k}$ $=$ response variable, $\mu=$ overall mean, $\alpha_{i}=$ the effect of inoculant treatment, $\beta_{j}=$ the effect of DM content treatment, $(\alpha \beta)_{i j}$ $=$ the interaction effect of inoculant and DM content, $e_{i j k}=$ error term. In addition, orthogonal coefficients for linear and quadratic contrast were adjusted to account for the unequal spacing of final DM concentration ( $35.4 \%$ vs $43.6 \%$ vs 51.5\%) with PROC IML before testing polynomial contrast with PROC GLM by SAS for significance [14]. The significant differences were declared at $\mathrm{p} \leq 0.05$.

\section{RESULTS}

\section{Chemical compositions of forage and silage}

There were no differences between CON forage and INO forage on all chemical compositions before ensiling (Table 1). Also, the increasing DM content of WCR forage had no effect on CP, CA, NDF, ADF, and HEMI before ensiling, except $\mathrm{EE}$ content that decreased linearly $(\mathrm{p}<0.001)$. The mean contents of CP, EE, CA, NDF, ADF, and HEMI from fresh WCR in the present study were $8.82 \%, 2.53 \%, 7.70 \%, 50.1 \%$, $28.0 \%$, and $22.1 \%$, respectively. The application of inoculant had no effects on the chemical compositions of WCR silage (Table 2). However, EE contents of WCR silage decreased linearly $(\mathrm{p}<0.001)$ with increasing DM content. 
Table 1. Chemical compositions of whole crop rice before ensiling (\%, DM)

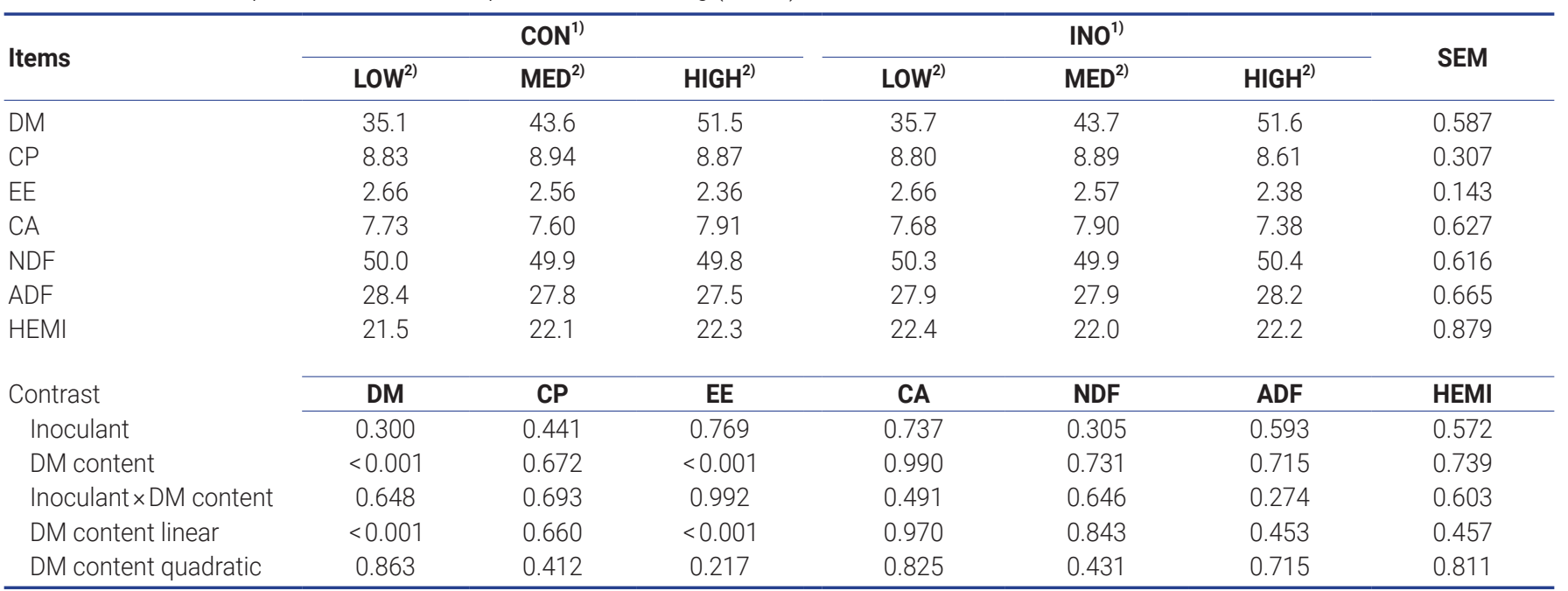

DM, dry matter; SEM, standard error of mean; CP, crude protein; EE, ether extract; CA, crude ash; NDF, neutral detergent fiber; ADF, acid detergent fiber; HEMI, hemicellulose.

1) CON, silage without inoculant; INO, silage inoculated with mixture of Lactobacillus brevis 5M2 and Lactobacillus buchneri 6M1 at ratio 1:1.

2) LOW, forage without wilting; MED, forage wilted for intermediate DM content; HIGH, forage wilted for high DM content.

Table 2. Effects of dual-purpose inoculant and DM content on chemical compositions of whole crop rice silage ensiled for $108 \mathrm{~d}(\%$, DM)

\begin{tabular}{|c|c|c|c|c|c|c|c|}
\hline \multirow{2}{*}{ Items } & \multicolumn{3}{|c|}{$\mathrm{CON}^{1)}$} & \multicolumn{3}{|c|}{ INO $^{1)}$} & \multirow{2}{*}{ SEM } \\
\hline & LOW $^{2)}$ & MED $^{2)}$ & $\mathrm{HIGH}^{2)}$ & LOW $^{2)}$ & MED $^{2)}$ & $\mathrm{HIGH}^{2)}$ & \\
\hline $\mathrm{DM}$ & 32.3 & 39.8 & 49.3 & 32.5 & 39.3 & 49.0 & 1.751 \\
\hline $\mathrm{CP}$ & 8.97 & 8.96 & 9.09 & 9.12 & 8.97 & 9.03 & 0.186 \\
\hline EE & 3.28 & 3.29 & 3.01 & 3.28 & 3.22 & 3.03 & 0.095 \\
\hline CA & 8.97 & 8.72 & 8.99 & 9.13 & 8.59 & 9.03 & 0.552 \\
\hline NDF & 55.0 & 56.1 & 55.5 & 54.6 & 54.8 & 53.8 & 1.396 \\
\hline ADF & 32.0 & 31.8 & 31.4 & 32.0 & 31.8 & 31.0 & 1.562 \\
\hline HEMI & 22.9 & 24.3 & 24.3 & 22.6 & 23.0 & 22.8 & 0.891 \\
\hline Contrast & DM & $\mathrm{CP}$ & EE & CA & NDF & ADF & HEM \\
\hline Inoculant & 0.855 & 0.656 & 0.859 & 0.942 & 0.622 & 0.844 & 0.204 \\
\hline DM content & $<0.001$ & 0.745 & 0.001 & 0.459 & 0.608 & 0.667 & 0.433 \\
\hline Inoculant $\times$ DM content & 0.933 & 0.456 & 0.708 & 0.908 & 0.742 & 0.963 & 0.346 \\
\hline DM content linear & $<0.001$ & 0.823 & $<0.001$ & 0.937 & 0.942 & 0.342 & 0.448 \\
\hline DM content quadratic & 0.073 & 0.375 & 0.042 & 0.170 & 0.326 & 0.829 & 0.403 \\
\hline
\end{tabular}

DM, dry matter; SEM, standard error of mean; CP, crude protein; EE, ether extract; CA, crude ash; NDF, neutral detergent fiber; ADF, acid detergent fiber; HEMI, hemicellulose.

1) CON, silage without inoculant; INO, silage inoculated with mixture of Lactobacillus brevis 5M2 and Lactobacillus buchneri 6M1 at ratio 1:1.

2) LOW, forage without wilting at ensiling; MED, forage wilted for intermediate DM content at ensiling; HIGH, forage wilted for high DM content at ensiling.

\section{Fermentation indices of silage}

The INO silages had higher $\mathrm{pH}(\mathrm{p}=0.025 ; 4.77$ vs 4.65$)$ and concentrations of acetate $(\mathrm{p}<0.001 ; 7.19 \%$ vs $3.20 \%)$ and propionate $(\mathrm{p}<0.001 ; 0.48 \%$ vs $0.00 \%)$ than those of $\mathrm{CON}$ silages, but had lower concentrations of lactate $(\mathrm{p}<0.001$; $3.42 \%$ vs $5.13 \%$ ) and butyrate ( $\mathrm{p}=0.022 ; 0.51 \%$ vs $1.24 \%$ ) and the ratio of lactate to acetate $(\mathrm{p}<0.001 ; 0.48$ vs 1.76$)$ (Table 3$)$. The silage $\mathrm{pH}$ increased linearly $(\mathrm{p}=0.021)$ with increasing DM content of WCR forage. On the other side, concentrations of ammonia- $\mathrm{N}(\mathrm{p}<0.001)$, lactate (tendency; $\mathrm{p}=0.068)$, acetate $(\mathrm{p}=0.030)$, and butyrate $(\mathrm{p}<0.001)$ de- creased linearly with increasing DM content of WCR forage. An interaction effect between inoculant and DM content was observed in the butyrate $(\mathrm{p}=0.024)$, where DM content showed an effect in CON silages.

\section{Microbial counts of silage}

In microbial counts, INO silages presented higher LAB count ( $p<0.001 ; 7.98$ vs $7.23 \log 10 \mathrm{cfu} / \mathrm{g}$ ) with lower mold count $(\mathrm{p}<0.001$; not detected vs $3.15 \log 10 \mathrm{cfu} / \mathrm{g})$ than CON silage (Table 4). Yeast count of WCR silage was not affected by inoculant application in the present study. However, yeast 
Table 3. Effects of dual-purpose inoculant and DM content on fermentation indices of whole crop rice silage ensiled for $108 \mathrm{~d}$

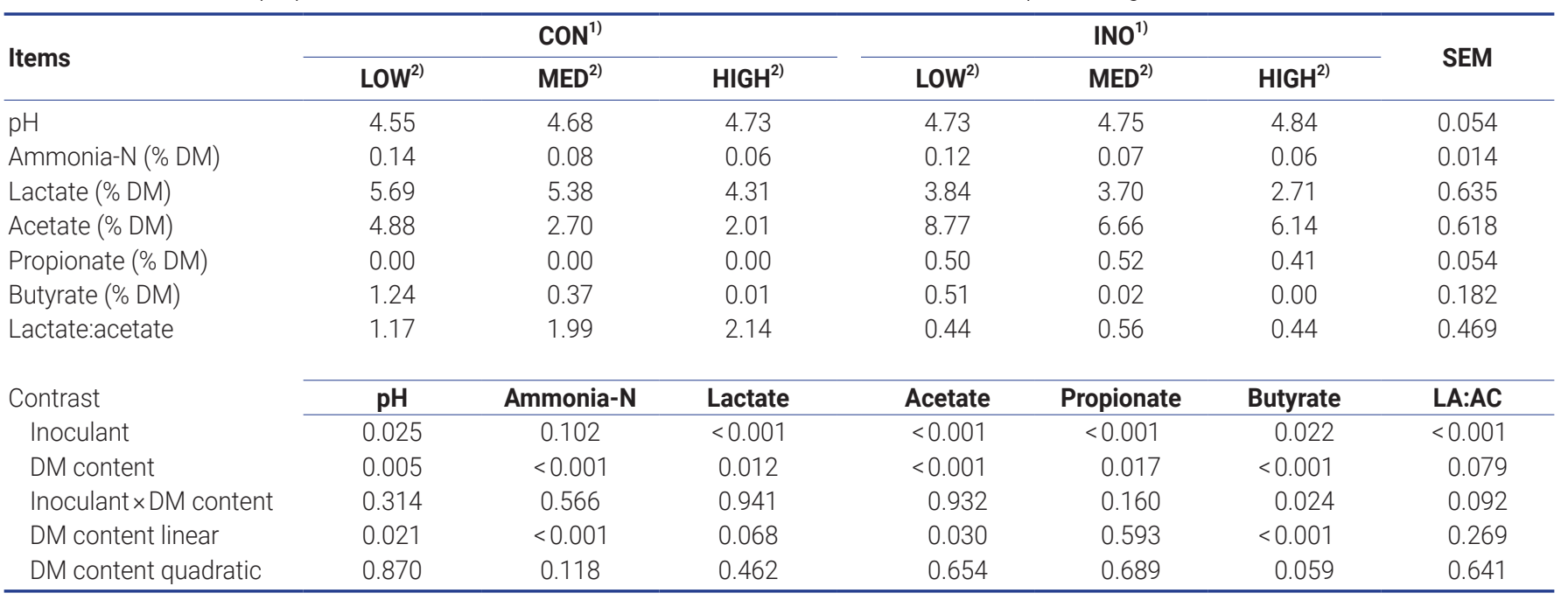

DM, dry matter; SEM, standard error of mean; LA:AC, lactate to acetate ratio.

1) CON, silage without inoculant; INO, silage inoculated with mixture of Lactobacillus brevis 5M2 and Lactobacillus buchneri 6M1 at ratio 1:1.

2) LOW, forage without wilting at ensiling; MED, forage wilted for intermediate DM content at ensiling; HIGH, forage wilted for high DM content at ensiling.

Table 4. Effects of dual-purpose inoculant and DM content on microbial count of whole crop rice silage ensiled for $108 \mathrm{~d}$ (log10 cfu/g)

\begin{tabular}{|c|c|c|c|c|c|c|c|}
\hline \multirow{2}{*}{ Items } & \multicolumn{3}{|c|}{$\mathrm{CON}^{1)}$} & \multicolumn{3}{|c|}{ INO $^{1)}$} & \multirow{2}{*}{ SEM } \\
\hline & LOW $^{2)}$ & MED $^{2)}$ & $\mathrm{HIGH}^{2)}$ & LOW $^{2}$ & MED $^{2)}$ & $\mathrm{HIGH}^{2)}$ & \\
\hline Lactic acid bacteria & 7.26 & 7.29 & 7.13 & 8.24 & 7.86 & 7.85 & 0.197 \\
\hline Mold & 3.25 & 3.05 & ND & ND & ND & ND & 0.043 \\
\hline Contrast & \multicolumn{3}{|c|}{ Lactic acid bacteria } & \multicolumn{2}{|c|}{ Yeast } & \multicolumn{2}{|c|}{ Mold } \\
\hline Inoculant $\times$ DM content & \multicolumn{3}{|c|}{0.133} & \multicolumn{2}{|c|}{0.914} & \multicolumn{2}{|c|}{$<0.001$} \\
\hline DM content linear & \multicolumn{3}{|c|}{0.271} & \multicolumn{2}{|c|}{0.042} & \multicolumn{2}{|c|}{0.046} \\
\hline DM content quadratic & \multicolumn{3}{|c|}{0.844} & \multicolumn{2}{|c|}{0.731} & \multicolumn{2}{|c|}{0.322} \\
\hline
\end{tabular}

DM, dry matter; SEM, standard error of mean; ND, not detected.

1) CON, silage without inoculant; INO, silage inoculated with mixture of Lactobacillus brevis 5M2 and Lactobacillus buchneri 6M1 at ratio 1:1.

2) LOW, forage without wilting at ensiling; MED, forage wilted for intermediate DM content at ensiling; HIGH, forage wilted for high DM content at ensiling.

count decreased linearly $(\mathrm{p}=0.042)$ with increasing DM content of WCR forage. On the other side, linear effect ( $p$ $=0.046$ ) with increasing DM was reported to decrease mold count in the present study.

\section{Rumen degradation kinetics}

In vitro rumen incubation for $72 \mathrm{~h}$ showed that INO silages had a higher potentially degradable fraction $(\mathrm{p}=0.001 ; 3.87$ vs $3.61 \mathrm{~mL} / \mathrm{g}$ ) and a total degradable fraction ( $\mathrm{p}<0.001 ; 4.53$ vs $4.40 \mathrm{~mL} / \mathrm{g}$ ), but a lower immediately degradable fraction ( $\mathrm{p}=0.032 ; 0.67 \mathrm{vs} 0.79 \mathrm{~mL} / \mathrm{g}$ ) and the fractional degradation rate was 0.07 vs $0.08(\mathrm{p}=0.011)$ compared with the CON silages (Table 5 ). On the other side, the potentially degradable fraction $(\mathrm{p}=0.024)$ and the total degradable fraction $(p=0.011)$ of WCR silage decreased linearly with increasing DM content of WCR forage, while the lag phase increased linearly $(\mathrm{p}<0.001)$.

\section{Rumen fermentation characteristics}

In rumen fermentation characteristics, INO silages had higher concentrations of total VFA (tendency; $\mathrm{p}=0.097 ; 231.7$ vs $229.4 \mathrm{mM} / \mathrm{L}$ ) and acetate ( $\mathrm{p}=0.007 ; 68.4 \%$ vs $67.8 \%$ molar), but lower concentration of propionate $(\mathrm{p}<0.001 ; 15.4 \%$ vs $16.0 \%$ molar) than CON silages (Table 6). Rumen $\mathrm{pH}$, ammonia-N, total VFA, iso-butyrate, iso-valerate, valerate, and acetate to propionate ratio were not affected by inoculant application. With increasing DM content of WCR forage, total VFA ( $\mathrm{p}=0.001)$, iso-butyrate $(\mathrm{p}=0.036)$, and valerate concentrations $(\mathrm{p}=0.008)$ of WCR silages decreased linearly. 
Table 5. Effects of dual-purpose inoculant and DM content on rumen degradation kinetics of whole crop rice silage ensiled for $108 \mathrm{~d}$

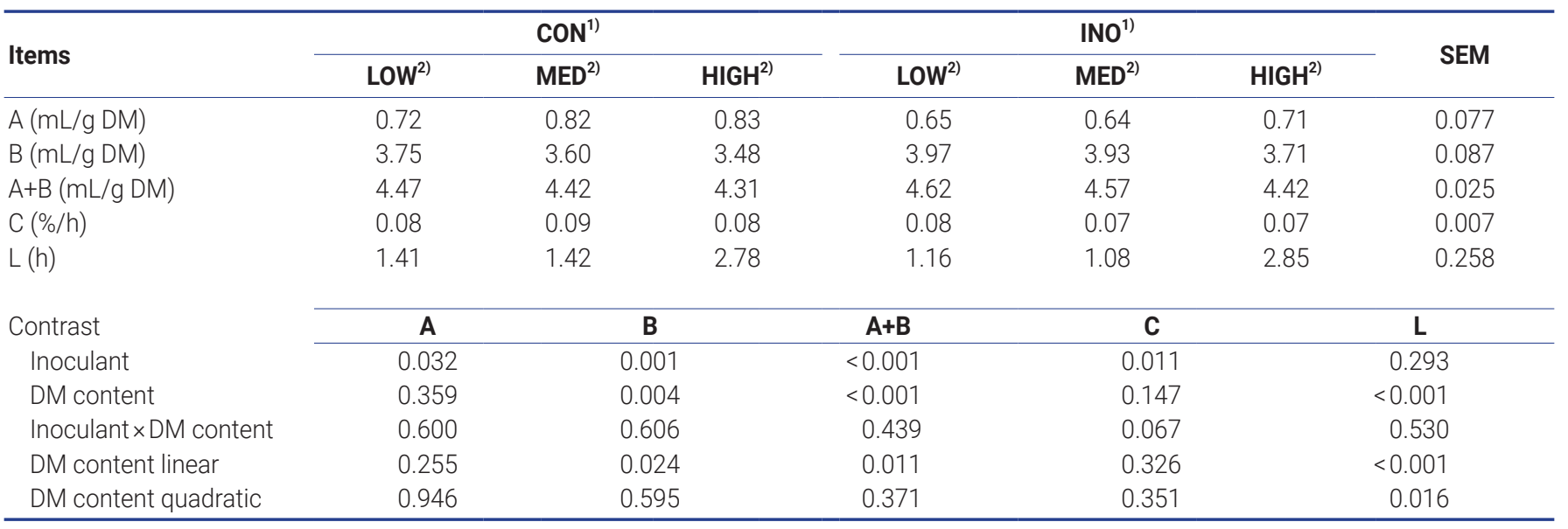

$\mathrm{DM}$, dry matter; SEM, standard error of mean; $A$, the immediately degradable fraction; $B$, the potentially degradable fraction; $A+B$, the total degradable fraction; $C$, the fraction degradation rate; $L$, the lag phase.

1) CON, silage without inoculant; INO, silage inoculated with mixture of Lactobacillus brevis 5M2 and Lactobacillus buchneri 6M1 at ratio 1:1.

2) LOW, forage without wilting at ensiling; MED, forage wilted for intermediate DM content at ensiling; HIGH, forage wilted for high DM content at ensiling .

Table 6. Effects of dual-purpose inoculant and DM content on rumen fermentation characteristics of whole crop rice silage ensiled for $108 \mathrm{~d}$

\begin{tabular}{|c|c|c|c|c|c|c|c|c|c|c|}
\hline \multirow{2}{*}{ Items } & \multicolumn{4}{|c|}{$\operatorname{CON}^{1)}$} & \multicolumn{5}{|c|}{ INO') } & \multirow{2}{*}{ SEM } \\
\hline & LOW $^{2}$ & & MED $^{2)}$ & $\mathrm{HIGH}^{2)}$ & & LOW $^{2)}$ & MED $^{2)}$ & & $\mathrm{HIGH}^{2)}$ & \\
\hline $\mathrm{pH}$ & 6.43 & & 6.40 & 6.44 & & 6.41 & 6.40 & & 6.43 & 0.027 \\
\hline Total VFA (mM/L) & 231.7 & & 231.0 & 225.4 & & 235.6 & 233.0 & & 226.5 & 2.088 \\
\hline Acetate (\% molar) & 67.4 & & 67.9 & 68.0 & & 68.2 & 68.1 & & 69.0 & 0.412 \\
\hline Propionate (\% molar) & 15.9 & & 16.2 & 16.0 & & 15.5 & 15.7 & & 14.9 & 0.205 \\
\hline Iso-valerate (\% molar) & 2.40 & & 2.23 & 2.21 & & 2.24 & 2.28 & & 2.25 & 0.077 \\
\hline Valerate (\% molar) & 0.98 & & 0.82 & 0.73 & & 0.88 & 0.93 & & 0.74 & 0.100 \\
\hline Acetate:propionate & 4.26 & & 4.20 & 4.26 & & 4.04 & 4.35 & & 4.65 & 0.247 \\
\hline Contrast & $\mathrm{pH}$ & $\mathrm{NH}_{3}-\mathrm{N}$ & TVFA & AC & PR & IBU & BU & IVA & VA & AC:PR \\
\hline DM content quadratic & 0.064 & 0.094 & 0.138 & 0.501 & 0.106 & 0.501 & 0.173 & 0.779 & 0.349 & 0.888 \\
\hline
\end{tabular}

DM, dry matter; SEM, standard error of mean; VFA, volatile fatty acid; $\mathrm{NH}_{3}-\mathrm{N}$, ammonia-N; TVFA, total volatile fatty acid; $\mathrm{AC}$, acetate; PR, propionate; IBU, iso-butyrate; $\mathrm{BU}$, butyrate; IVA, iso-valerate; $\mathrm{VA}$, valerate; $\mathrm{AC}: \mathrm{PR}$, acetate to propionate ratio.

1) CON, forage ensiled without inoculant; INO, forage ensiled with mixture of Lactobacillus brevis 5M2 and Lactobacillus buchneri 6M1 at ratio 1:1.

2) LOW, forage without wilting at ensiling; MED, forage wilted for intermediate DM content at ensiling; HIGH, forage wilted for high DM content at ensiling.

\section{DISCUSSION}

In general, the chemical compositions of fresh WCR forage in the present study were in a normal range according to several previous studies [16,17]. In addition, decreasing EE content of WCR in the present study was associated with increasing level of DM content. A wilting process under the sun to increase DM content evidently could decrease the EE content in the forage due to the oxidation process $[18,19]$, which was in agreement with the result of EE in the present study. After ensiling, $\mathrm{pH}$ and organic acid from all silages were similar to the previous studies $[20,21]$ and represented high quality of fermentation, which could inhibit nutrient loss during fermentation in WCR silage (Table 3). This might be a reason for the lack of an effect of inoculant application on $\mathrm{CP}, \mathrm{NDF}, \mathrm{ADF}, \mathrm{HEMI}$ of WCR silage. Low $\mathrm{pH}$ condition inhibited the growth of undesirable microbes and stopped the natural enzymes from degrading protein and carbohy- 
drate during ensiling [9]. In addition, the result of EE content after ensiling followed the result of EE content before ensiling because the condition in all silages were acid enough to inhibit the lipid oxidation during ensiling $[9,19]$. Thus, only the effect of DM content affected the EE content after ensiling without any effect from inoculant. On the other side, a lower DM content of WCR after ensiling than before ensiling in all treatments indicated that soluble carbohydrate was used by silage microbes to grow and produce organic acid [9]. The lose of DM content during ensiling could change the percentage of the other chemical composition in silages. Therefore, this was a reason of increasing content of other chemical compositions such as $\mathrm{CP}, \mathrm{EE}, \mathrm{NDF}, \mathrm{ADF}$, and HEMI in WCR after ensiling.

The WCR silage had $\mathrm{pH}$ range at 4.40 to 5.00 in previous studies [20,21], which was like the results in the present study. The lower $\mathrm{pH}$ in CON silages than in INO silages were caused by high lactate production, which lactate had highest degree of acidification compared with acetate, propionate or butyrate $[9,22]$. Inoculants in the present study, L. brevis $5 \mathrm{M} 2$ and $L$. buchneri $6 \mathrm{M} 1$, are classified as hetero fermentative LAB, where these LAB could convert the lactate into acetate or propionate [9]. This was a reason for the lower lactate concentration and higher concentrations of acetate and propionate in INO silages than in $\mathrm{CON}$ silages. In general, $\mathrm{CON}$ silage presented higher ammonia-N and butyrate concentrations than INO silage in all of DM contents. The presence of ammonia-N and butyrate could be indicators of the nutrient degradation by undesirable microbes $[9,22]$. Moreover, the presence of those compounds would decrease feed palatability for ruminant $[9,23]$. The higher production of antimicrobial compounds including acetate and propionate in INO silages inhibited the undesirable microbes such as mold (Table 4), and then could potentially increase the aerobic stability of silage $[22,24]$. The results of present study were supported by several previous studies that reported decreases of ammonia- $\mathrm{N}$ and butyrate concentrations in silage following inoculant application $[3,4]$. On the other side, silage $\mathrm{pH}$ increased with increasing DM content of WCR forages that was appropriate with decreasing lactate and acetate concentrations of WCR silages. Decreasing moisture content decreased organic acid such as lactate and acetate production in the silage because LAB have low activity in low moisture silage $[9,25]$. This supported the result of LAB count in the present study (Table 4) where LAB numerically decreased with increasing DM content of WCR forages. In addition, ammonia- $\mathrm{N}$ concentration also decreased with increasing DM content of WCR forages that was in agreement with decreases of yeast and mold counts in WCR silage (Table 4).

In microbial count, higher LAB count by inoculant application agreed with previous studies [3,4]. The present study reported that mold count also decreased by inoculant appli- cation, which confirmed an antifungal activity of L. brevis $5 \mathrm{M} 2$ and L. buchneri $6 \mathrm{M} 1$. Similar with the present study, application of antifungal-producing inoculant could inhibit the growth of mold in silage [26]. The increasing DM content of WCR forages lead to decreases of yeast and mold counts in the present study. Previous studies have shown limitations of growth on those microbes in silage with low moisture content $[9,25]$.

In general, rumen degradation kinetics reflects the result of the rumen digestibility [27]. In the present study, the immediately degradable fraction decreased by inoculant application that supported the increases of LAB count (Table 4) and total organic acid (lactate and acetate; Table 3 ) in INO silages. A high population of LAB in INO silages increased the use of the immediately degradable fraction, such as soluble carbohydrate during ensiling to support their maintenance and produce more organic acid [9]. Thus, remain of soluble carbohydrate was lower in INO silages than in CON silages. However, the application of L. brevis 5M2 and L. buchneri $6 \mathrm{M} 1$ on WCR silage had proven to improve nutrient digestibility by increase degradation of the potentially degradable fraction and the total degradable fraction in the rumen. Both these LABs produce carboxylesterase that could break down the lignin complex, and then increased the accessibility of other fibrinolytic enzymes to degrade structural carbohydrate in the silage [2]. Similar to the present study, several previous studies also reported the improvement of rumen digestibility by application of inoculant producing esterase $[4,5]$. The reason for the lower the fractional degradation rate in INO silages was unclear. The LAB from silage could pass and survive in the rumen ecosystem, but their interaction with rumen microbes digesting the silage was unknown $[27,28]$. The interaction between silage inoculant and rumen microbes resulted in the lower rate of fractional degradation such as the result of INO silages in the present study. Nevertheless, the low fractional degradation rate didn't always influence the total degradable fraction. On the other side, higher total degradable fraction in INO silages also supported with higher total VFA and acetate concentration than in CON silages. Increasing concentration of total VFA with a high acetate proportion indicated a high digestibility of structural carbohydrate in the rumen [27,29], where structural carbohydrate was the main chemical composition of WCR silage. High proportion of acetate in the rumen could decrease the propionate proportion [27,29], which supported the result of INO silages in the present study. The previous study reported that increasing DM content at ensiling had no effect on digestibility and fermentation characteristics of alfalfa silage in the rumen [25]. However, Santos and Kung [30] reported that low DM content at ensiling had higher rumen NDF digestibility than high DM content, which was in agreement with the result of the present study. With in- 
creasing DM content of WCR forage, the potentially and total degradable fractions decreased that supported the decreases of total VFA, iso-butyrate, and valerate concentrations in the present study. These results indicated that the nutrient digestibility of WCR silage decreased with increasing DM content of WCR forage.

\section{CONCLUSION}

The present study concluded that application of antifungal and carboxylesterase-producing inoculant on WCR silage improved acetate concentration, mold inhibition, and rumen digestibility in all DM contents. Mold was not detected when DM was at haylage levels in either CON or INO silages. With increasing DM content of WCR forage, fermentation indices and rumen digestibility of WCR silage decreased. The present study confirmed that antifungal and esterase activities of the inoculants were effective at the DM levels for making silage or intermediate between silage and haylage.

\section{CONFLICT OF INTEREST}

We certify that there is no conflict of interest with any financial organization regarding the material discussed in the manuscript. Ji KB an employee of Livemac Co. Ltd.

\section{ACKNOWLEDGMENTS}

This research was supported (Project No. 319039-03-2HD020) by IPET (Korea Institute of Planning and Evaluation for Technology in Food, Agriculture, Forestry and Fisheries), and Ministry of Agriculture, Food and Rural Affairs, Republic of Korea.

\section{REFERENCES}

1. Alonso VA, Pereyra CM, Keller LAM, et al. Fungi and mycotoxins in silage: an overview. J Appl Microbiol 2013;115:63743. https://doi.org/10.1111/jam.12178

2. Adesogan AT, Ma ZX, Romero JJ, Arriola KG. Ruminant nutrition symposium: improving cell wall digestion and animal performance with fibrolytic enzymes. J Anim Sci 2014;92:1317-30. https://doi.org/10.2527/jas.2013-7273

3. Paradhipta DHV, Joo YH, Lee HJ, et al. Effects of inoculant application on fermentation quality and rumen digestibility of high moisture sorghum-sudangrass silage. J Appl Anim Res 2019;47:486-91. https://doi.org/10.1080/09712119.2019. 1670667

4. Paradhipta DHV, Lee SS, Kang B, et al. Dual-purpose inoculants and their effects on corn silage. Microorganisms 2020;8: 765. https://doi.org/10.3390/microorganisms8050765

5. Paradhipta DHV, Joo YH, Lee HJ, et al. Effects of wild or mutated inoculants on rye silage and its rumen fermentation indices. Asian-Australas J Anim Sci 2020;33:949-56. https:// doi.org/10.5713/ajas.19.0308

6. Schnürer J, Magnusson J. Antifungal lactic acid bacteria as biopreservatives. Trends Food Sci Technol 2005;16:70-8. https://doi.org/10.1016/j.tifs.2004.02.014

7. Aquino D, Del Barrio A, Trach NX, et al. Rice straw-based fodder for ruminants. In: Gummert M, Van Hung N, Chivenge P, Douthwaite B, editors. Sustainable rice straw management. Cham, Switzerland: Springer; 2020. pp. 111-29.

8. Zhao J, Dong Z, Li J, et al. Effects of sugar sources and doses on fermentation dynamics, carbohydrates changes, in vitro digestibility and gas production of rice straw silage. Ital J Anim Sci 2019;18:1345-55. https://doi.org/10.1080/1828051X. 2019.1659106

9. McDonald P, Henderson AR, Heron SJE. The biochemistry of silage, 2nd ed. Marlow, Bucks, UK: Chalcombe Publications; 1991. pp. 248-91.

10. AOAC International. Official methods of analysis. 18th ed. Washington DC, USA: AOAC International; 2005.

11. Chaney AL, Marbach EP. Modified reagents for determination of urea and ammonia. Clin Chem 1962;8:130-2. https:// doi.org/10.1093/clinchem/8.2.130

12. Muck RE, Dickerson JT. Storage temperature effects on proteolysis in alfalfa silage. Trans ASAE 1988;31:1005-9. https:// doi.org/10.13031/2013.30813

13. Adesogan AT, Krueger NK, Kim SC. A novel, wireless, automated system for measuring fermentation gas production kinetics of feeds and its application to feed characterization. Anim Feed Sci Technol 2005;123-4:211-23. https://doi.org/ 10.1016/j.anifeedsci.2005.04.058

14.SAS Institute Inc. SAS/STAT User's guide: version 9. Cary, NC, USA: SAS Institute Inc.; 2002.

15. McDonald I. A revised model for the estimation of protein degradability in the rumen. J Agric Sci 1981;96:251-2. https:// doi.org/10.1017/S0021859600032081

16. Wanapat M, Kang S, Khejornsart P, Pilajun R, Wanapat S. Performance of tropical dairy cows fed whole crop rice silage with varying levels of concentrate. Trop Anim Health Prod 2014;46:185-9. https://doi.org/10.1007/s11250-013-0473-5

17. Takahashi T, Horiguchi K, Goto M. Effect of crushing unhulled rice and the addition of fermented juice of epiphytic lactic acid bacteria on the fermentation quality of whole crop rice silage, and its digestibility and rumen fermentation status in sheep. Anim Sci J 2005;76:353-8. https://doi.org/10.1111/j. 1740-0929.2005.00275.x

18. Boufaïed H, Chouinard PY, Tremblay GF, Petit HV, Michaud R, Bélanger G. Fatty acids in forages. I. Factors affecting concentrations. Can J Anim Sci 2003;83:501-11. https://doi. org/10.4141/A02-098

19. Roffler RE, Niedermeier RP, Baumgardt BR. Evaluation of alfalfa-brome forage stored as wilted silage, low-moisture 
silage, and hay. J Dairy Sci 1967;50:1805-13. https://doi.org/ 10.3168/jds.S0022-0302(67)87719-1

20. Kim BW, Kim GS, Sung KI. Effect of lactic acid bacteria and formic acid on the silage quality of whole crop rice at different maturity. J Korean Soc Grassl Forage Sci 2004;24:61-70. https:// doi.org/10.5333/KGFS.2004.24.1.061

21.Kim JG, Chung ES, Seo S, et al. Effect of growth stage and variety on the quality of whole crop rice silage. J Korean Soc Grassl Forage Sci 2008;28:29-34. https://doi.org/10.5333/ KGFS.2008.28.1.029

22.Danner H, Holzer M, Mayrhuber E, Braun R. Acetic acid increases stability of silage under aerobic conditions. Appl Environ Microbiol 2003;69:562-7. https://doi.org/10.1128/ AEM.69.1.562-567.2003

23. Nkosi BD, Meeske R. Effects of ensiling totally mixed potato hash ration with or without a heterofermentative bacterial inoculant on silage fermentation, aerobic stability, growth performance and digestibility in lambs. Anim Feed Sci Technol 2010;161:38-48. https://doi.org/10.1016/j.anifeedsci.2010. 07.015

24.Lee SS, Lee HJ, Paradhipta DHV, et al. Temperature and microbial changes of corn silage during aerobic exposure. Asian-Australas J Anim Sci 2019;32:988-95. https://doi.org/ 10.5713/ajas.18.0566
25.Han KJ, Collins M, Vanzant ES, Dougherty CT. Bale density and moisture effects on alfalfa round bale silage. Crop Sci 2004;44:914-9. https://doi.org/10.2135/cropsci2004.9140

26. Kleinschmit DH, Schmidt RJ, Kung L. The effects of various antifungal additives on the fermentation and aerobic stability of corn silage. J Dairy Sci 2005;88:2130-9. https://doi.org/10. 3168/jds.S0022-0302(05)72889-7

27. Hobson PN, Stewart CS. The rumen microbial ecosystem, 2nd ed. London, UK: Blackie Academic and Professional; 1997. pp. 543-708.

28. Weinberg ZG, Chen Y, Gamburg M. The passage of lactic acid bacteria from silage into rumen fluid, in vitro studies. J Dairy Sci 2004;87:3386-97. https://doi.org/10.3168/jds.S00220302(04)73474-8

29. Sutton JD, Dhanoa MS, Morant SV, France J, Napper DJ, Schuller E. Rates of production of acetate, propionate, and butyrate in the rumen of lactating dairy cows given normal and low-roughage diets. J Dairy Sci 2003;86:3620-33. https:// doi.org/10.3168/jds.S0022-0302(03)73968-X

30. Santos MC, Kung L. Short communication: the effects of dry matter and length of storage on the composition and nutritive value of alfalfa silage. J Dairy Sci 2016;99:5466-9. https://doi. org/10.3168/jds.2016-10866 